\title{
Site Characterization for Construction Purposes at FUNAAB using Geophysical and Geotechnical Methods
}

\author{
Geofizilkalna in Geotehnična Ocena \\ Gradbene Lokacije v Funaabu v Nigeriji
}

\author{
Alabi, A.A. ${ }^{1 *}$, Adewale, A.0. ${ }^{2}$, Coker, J.O. ${ }^{3}$, Ogunkoya, O.A. ${ }^{1}$ \\ ${ }^{1}$ Department of Physics, College of Physical Sciences, Federal University of Agriculture, Abeokuta (FUNAAB), Nigeria \\ 2 Department of Science Laboratory Technology, Moshood Abiola Polytechnic, Abeokuta, Nigeria \\ ${ }^{3}$ Department of Physics, Faculty of Science, Olabisi Onabanjo Univesity, Ago Iwoye, Nigeria \\ *derylab@yahoo.com
}

\begin{abstract}
Geophysical and geotechnical techniques were used to investigate the sub-surface information of a proposed site for a hostel construction at Federal University of Agriculture, Abeokuta. Ten vertical electrical sounding (VES) stations were adopted. Typical sounding curves obtained include the $\mathrm{HA}, \mathrm{KH}, \mathrm{AKH}$ and $\mathrm{KQH}$ types, of which the AKH-type consists of $40 \%$ of the survey points, and a maximum of five geo-electric sub-surface layers were delineated. Laboratory analyses were performed to investigate particle size distribution, Atterberg limit, compaction limit, California bearing ratio (CBR) and specific gravity. The CBR revealed that all soil samples, except L4, are mechanically stable and have high load-bearing capacity. The Atterberg limit test and the geo-electric section showed that the second layer of VES 4 is composed of sandy clay with high plastic index and low liquid limit, which may pose a threat to the foundation of any engineering structure. VES locations 5, 6 and 8 were identified as high groundwater potential zones suitable for optimum groundwater abstraction. The study area is suitable for both shallow and deep foundations, however VES 4 and VES 5 require reinforcement.
\end{abstract}

Key words: grain size, California bearing ratio, Atterberg limits, compaction

\section{POVZETEK}

Za vrednotenje globinske informacije na predlagani lokaciji za hostel pri Zvezni poljedelski univerzi v Abeokuti so uporabili geofizikalne in geotehnične metode. Podatke so pridobili na desetih postajah z vertikalnim električnim sondiranjem (VES). Izmed značilnih krivulj $\mathrm{HA}, \mathrm{KH}, \mathrm{AKH}$ in $\mathrm{KQH}$ obsegajo tiste vrste $\mathrm{AKH} 40 \%$ izmerjenijh točk, kar je omogočilo opredeliti v globini pet geoelektričnih plasti. V laboratorijiu so opravili preiskavo porazdelitve zrnavosti, Atterbergove konsistenčne meje, kompakcijski preskus, California bearing ratio (CBR) in specifično težo. CBR nakazuje, da so vsi vzorci tal mehansko obstojni in da imajo visoko obremenilno kapaciteto z edino izjemo vzorca L4. Rezultati določitev Atterbergovih mej in geoelektričnih lastnosti pričajo o tem, da vsebuje druga plast VES 4 peščeno glino z visokim indeksom plastičnosti in nizko tekočinsko mejo, kar utegne ogrožati temeljenje. Lege VES 5, VES 6 in VES 8 razlagajo kot cone visokega potenciala podzemne vode, ki so lahko primerne lokacije za črpanje podtalnice. Preiskano območje je primerno tako za plitvo kot tudi globoko temljenje z izjemo lokacij VES 4 in VES 5, na katerih bo potrebno ojačenje.

Ključne besede: zrnavost, preskus California bearing ratio, Atterbergove meje, stisljivost 


\section{Introduction}

In recent years, reports on collapsed structures have become alarming [1-4], and this phenomenon had led to loss of life and properties. It has been reported $[5,6]$ that building collapse may be due to inadequate bearing pressure, poor building materials, foundation failures which are traceable to lack or improper geo-technical and geophysical investigations, as well as effects of vibrations or fluctuations in water level. In recent years, collapse of engineered structures have become widespread going by the number of failed structures. Most of these failures can be attributed to insufficient knowledge of the bedrock of the sites, inaccurate top soil profile information, failure to identify sub-surface voids or solution cavities in carbonate rocks and lack of information on competence of the soil strata among others $[7,8]$. Part of the concern in the design of structures is the pre-construction investigation of the subsoil which is to be carried out at the proposed location to ascertain the fitness of the host earth materials. The electrical resistivity method is useful in determining the competence of the subsoil layers; the resistivity value of the soil strata is proportional to its competence, and this value is governed by the amount of pore space and the arrangement of the pores, soil particle size and arrangement, among others [9]. Electrical resistivity measurements are preferred because of the wide range of resistivity values that are associated with nature, and it is also cost-effective among other geophysical surveys. The method is suitable for estimating depth of the bedrock and identifying the presence of structural features in the bedrock or potentially hazardous sub-surface conditions before the engineering structure is put in place [10]. The electrical resistivity method had found landmark success in solving a wide variety of engineering and environmental problems [11-19]. Application of 2D electrical resistivity tomography (ERT) in geo-technical investigations of the foundation at Ogudu Lagos, Nigeria [20], showed that the depth to the competent layer that could support a sizeable engineering structure is confined to the second half of the surveyed northeast area at a deeper depth mapped by ERT.
Electromagnetic profiling, dipole-dipole profiling and geo-electric depth sounding were integrated to carry out post-foundation engineering geophysical investigation within the surroundings of the 2,500 capacity auditorium building, Federal University of Technology, Akure, Nigeria [21]. The geo-electric sections and the inverted 2D resistivity structures delineated four sub-surface geo-electric layers, which include the topsoil, weathered layer weathered/fractured basement and the resistive basement bedrock. The study revealed that the sub-surface geologic materials underlying the investigated building are characterized by the presence of heterogeneous near-surface geo-materials, as well as uneven basement topography at shallow depths, where the foundations are usually placed. These features constitute a zone of geo-technical weakness, which may precipitate subsidence-related failure and eventual collapse of the foundation of the building.

Faseki et al. [22] used the geo-technical method to determine the geo-stratigraphy and engineering properties of the soil in shallow formations as foundation material in a proposed construction site along Badore Road, Addo, Lagos, Nigeria. Two boreholes were drilled up to the depth of $30.0 \mathrm{~m}$, while cone penetration tests (CPTs) were deployed up to a depth of $6.0 \mathrm{~m}$. Samples from boreholes were subjected to grain size and Atterberg limit tests. The results revealed that the site is underlain essentially by soft silty sandy clay at the upper layer, characterized by void ratio, unit weight, average standard penetration testing SPT-N and natural water content values, which are indicative of poor foundation material.

Oyedele et al. [23] carried out an integrated geophysical and geo-technical survey on a proposed engineering site at Ikoyi, Lagos, Nigeria. The investigation used CPT and SPT. Geophysical and geo-technical tests showed good agreement. Four to five sub-surface layers were delineated within the study area: the topsoil loose sand, peat/clay, sandy clay, sand and clay, which indicate good correlation with the soil layers in the bore logs. The existence of loose sand, peat and clay near the surface is capable of being inimical to building structures.

Site characterization involves determination of the nature and behaviour of all those aspects of 


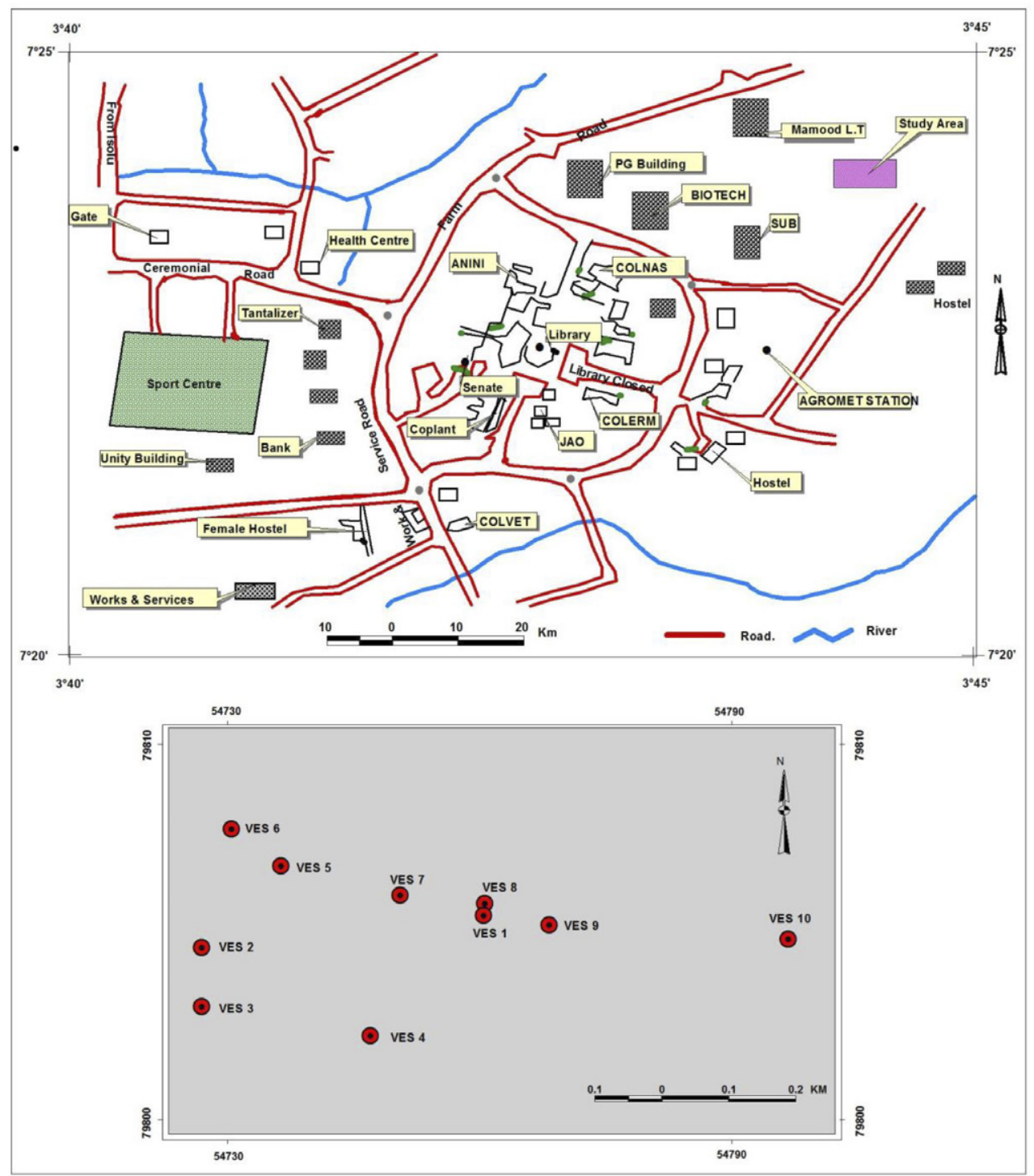

Figure 1: The Topography Map of the Study Area.

a site and its environment that could significantly influence or be influenced by an engineering construction project. The main reason for site characterization is to have adequate, dependable information of the sub-surface and site conditions, which will assist in taking decisions during the consideration, design and execution of an engineering construction project. The aim of this work is to investigate the nature and engineering properties of the proposed site for the proper designing of the foundation for the proposed hostel building at Federal University of Agriculture Abeokuta (FUNAAB). The study used geophysical and geotechnical techniques to probe the sub-surface competence and struc- tural disposition in terms of load bearing in the context of building construction.

\section{Materials and Methodology}

\section{Description of the Study Area}

The study area is a proposed site for students` hostel located near the student union building within FUNAAB campus in Odeda Local Government Area of Abeokuta, Ogun State, Southwest Nigeria (Figure 1). It is located between latitudes $7^{\circ} 12^{\prime} 00^{\prime \prime}$ and $7^{\circ} 30^{\prime} 00^{\prime \prime}$ and between longitudes $3^{\circ} 15^{\prime} 00^{\prime \prime}$ and $3^{\circ} 45^{\prime} 00^{\prime \prime}$. 


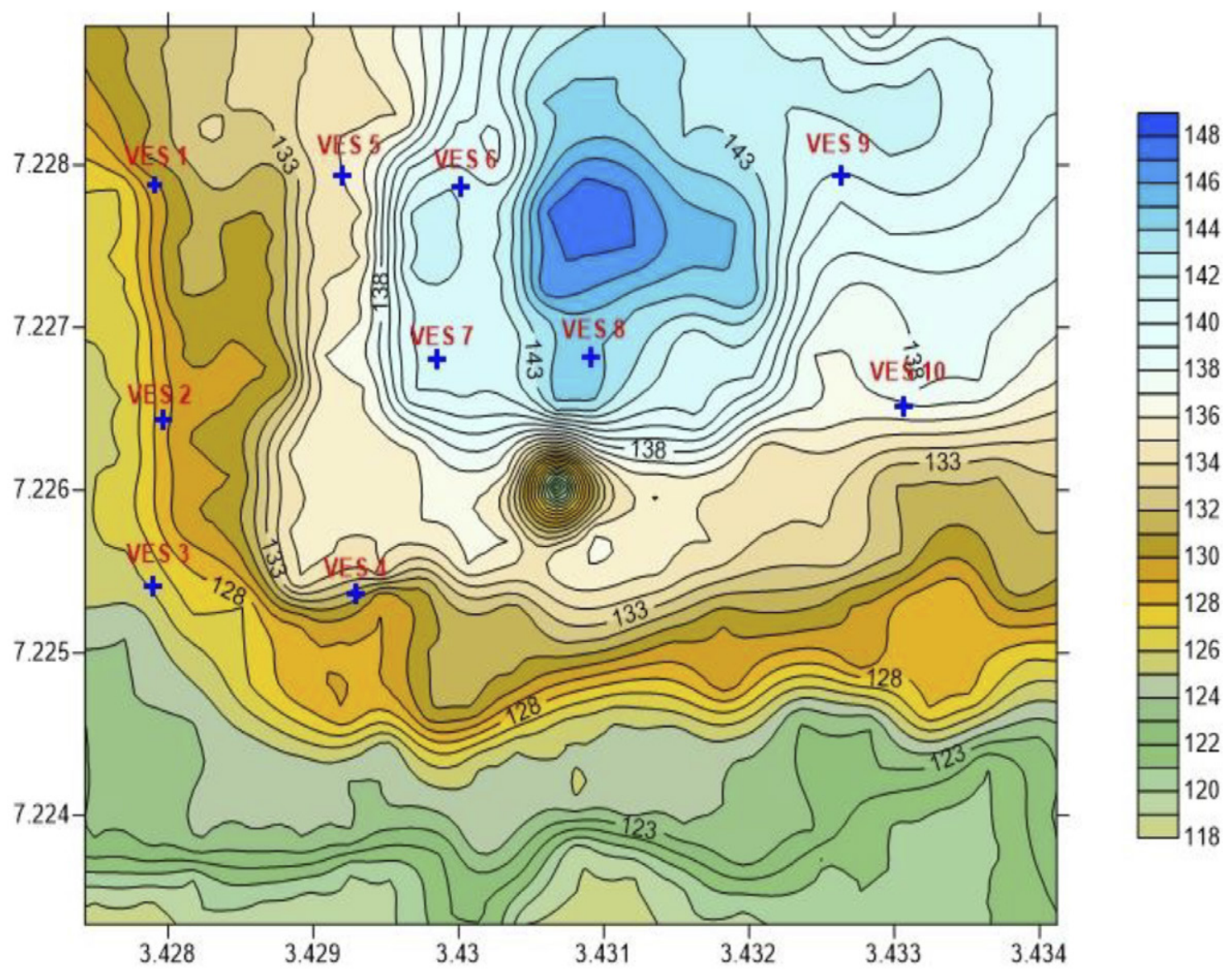

Figure 2: Digital Elevation Model in Three Dimensions.

\section{Geology and Hydrological Settings of the Study Area}

The ground elevation around the site of investigation ranges from 371 to $379 \mathrm{~m}$ above sea level (Figure 2), with the top soil mainly composed of sand, sandy clay and laterite. The topography of the area is slightly even, with some areas sloping gently. The climate is hot and humid, influenced by rain-bearing southwest monsoon winds from the ocean and dry northwest winds from the Sahara Desert. The study area, which falls within the Precambrian basement complex of Southwestern Nigeria [24-26], is underlain by crystalline rocks. The lithological units include magmatic gneiss complex, granitic gneiss and charnockites (Figure 3). Boulders of gneiss and granitic gneiss occur in the western part of the study area. Fracture bedrock generally occurs in a typical basement terrain [27]. The study area lies within the basement complex rocks. These rocks are from the Precambrian age to the early Palaeozoic age, and they extend from the northeastern part of Ogun State (to which Abeokuta belongs), running in the southwest direction and dipping towards the coast [28].

\section{Field Work Procedure for Geophysical \\ Survey}

The vertical electrical sounding (VES) approach of the electrical resistivity technique was adopted to determine the electrical resistivity and depths of the sub-surface layer with a highly sensitive terrameter (ABEM 300) using Schlumberger electrode arrangement (Figure 4). When the ratio of the distance between the current electrodes and the potential electrodes became too large, the potential electrodes were displaced outwards; otherwise, the potential difference may become too small to be measured with sufficient accuracy [29, 30]. Measurements 


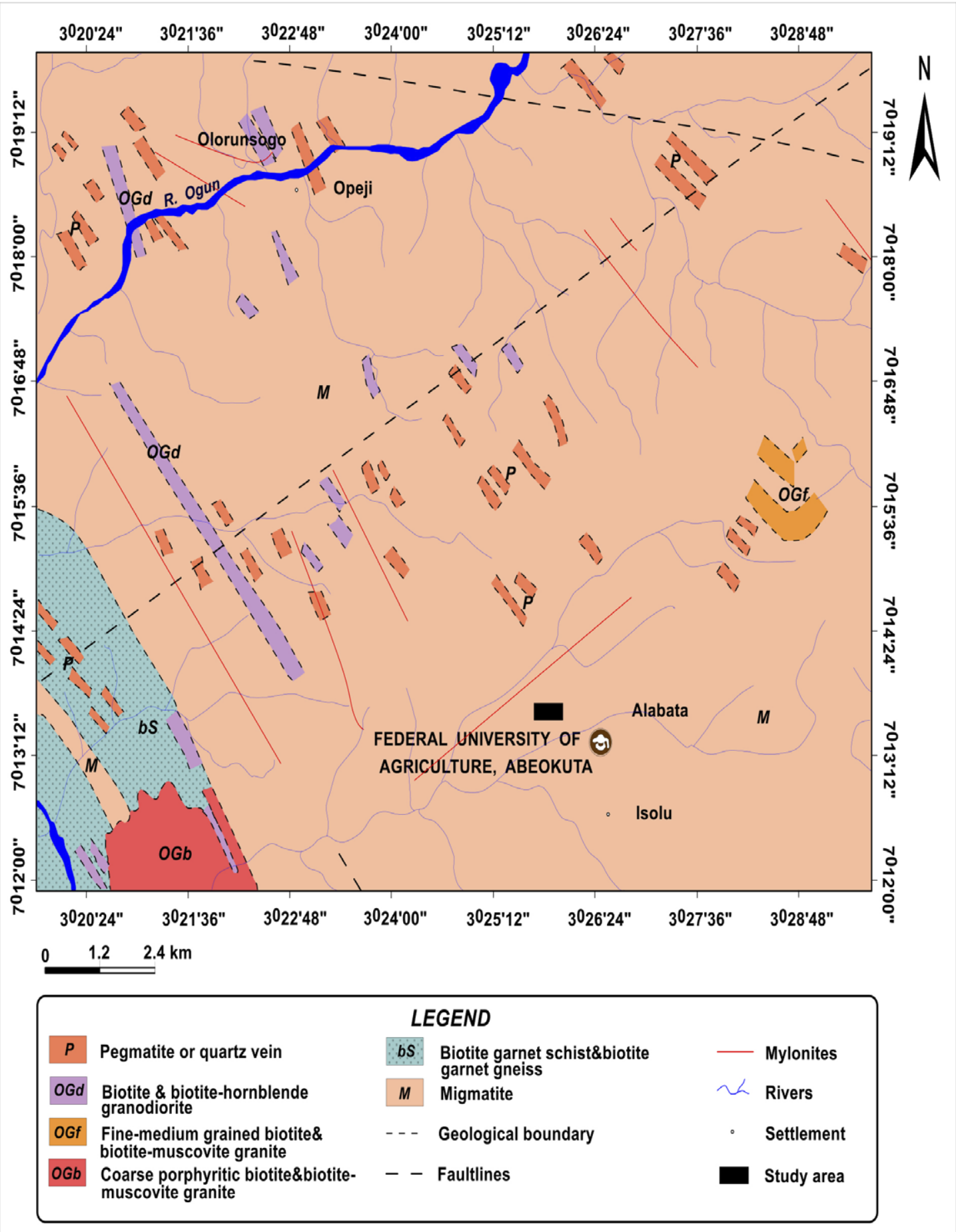

Figure 3: Geological Map of the part of Abeokuta showing the study area.

of current and the potential electrode positions were marked such that $\mathrm{AB} / 2 e^{\frac{M N}{2}}$, where $\mathrm{AB} / 2=$ current electrode spacing and $\mathrm{MN} / 2=$ potential electrode spacing. The value of $\mathrm{AB} / 2$ increased as the measurement progressed, while the po- tential electrodes' separations were guided accordingly. The potential electrodes were kept at small separations relative to the current electrodes' separations $[30,31]$. One of the major advantages of this method relative to other methods is that only the current electrodes 


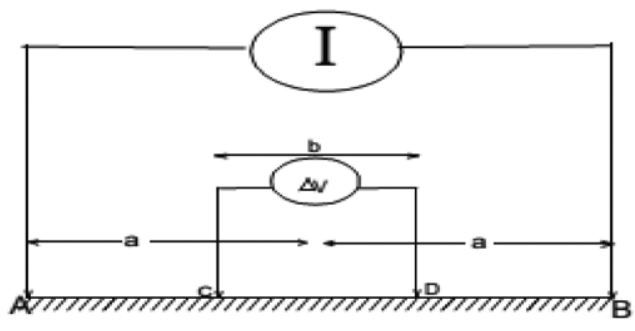

Figure 4: Schlumberger array configuration, where I is the current, $a$ is the midpoint between the current electrodes, $b$ is the distance between the potential electrodes and $\Delta V$ is the potential difference between the two potentials $C$ and $D$.

need to be moved to new positions for most readings, while the potential electrodes are kept constant for up to three or four readings $[30,32]$. During the field work sounding, the earth resistivity meter performs automatic recording of both voltage and current, stacks the results, computes the resistance in real time and digitally displays them $[30,33]$.

The apparent resistivity value is the product of the geometric factor and the resistance recorded in the resistivity meter. Several soundings and apparent resistivity values would be obtained by progressively expanding the current electrodes' spacing with fixed steps to enable sufficient penetration to the sub-surface earth and enhance structural responses as specified by Schlumberger arrays.

\section{Laboratory Tests for Geo-technical Survey}

Disturbed soil samples (15 kg each) were collected at each of the locations of the seven VES stations - L2 (VES2), L4 (VES4), L5 (VES5), L6 (VES 6), L7 (VES7), L8 (VES8) and L10 (VES10) within the site. The samples were put inside black polythene bags, labelled and packed under controlled temperature to prevent the escape of moisture. The analysis was carried out at Civil Engineering Laboratory, Federal University of Agriculture, Abeokuta. Analysis of samples was extended to include California bearing ratio (CBR) test, specific gravity determination, grain size analysis (sieve analysis) test, compaction test and Atterberg limits test. Samples were prepared depending on the investigation types and procedures used. Some samples were wet and compacted, some were oven-dried and sieved with a specific sieve number, some were soaked in distilled water, some were pulverised and run through a known sieve, while some were crushed with a rubber-headed pestle and sieved before the analysis was carried out on them. Laboratory equipment deployed for the analysis were electric oven, sieve shaker, plastic mortar and pestle, Casagrande's liquid limit (LL) apparatus, density bottle with distilled water and gassing machine.

The CBRs of soaked and unsoaked soils were determined using a standard method (American Society for Testing and Materials [ASTM] D1883). The test was carried out on the top and bottom layers of the compacted wet soil, and the average was taken as the actual CBR. A water pycnometer-based standard test (ASTM D854-00) was used to determine the specific gravity of the soil.

The specify gravity of the soil solids was calculated using Equation (1):

Specify gravity,

$$
G_{S}=\frac{w_{o}}{w_{o}+\left(w_{a}-w_{b}\right)}
$$

where

$w_{o}=$ weight of sample of oven-dry soil, $g=w_{p s}-w_{p}, w_{a}=$ weight of pycnometer filled with water and $w_{b}=$ weight of pycnometer filled with water and soil.

The grain sieve analysis was performed to determine the percentage by weight of the grains passing through a $75 \mu \mathrm{m}$ sieve (sieve no. 200). Samples of approximately $500 \mathrm{~g}$ were used for determining grain size distribution. The percentages of particles retained and particles passing were calculated using Equations (2) and (3).

$R=\frac{M_{r}}{T_{m}} * 100$

$P=100-R$

$Q_{p}=T_{m}-M_{r}$

where $T_{m}=$ total mass of the soil, $R=\%$ retained, $P=\%$ passing, $M_{r}=$ mass retained, $Q_{p}=$ quantity passing.

The compaction test was used to investigate the moisture-density relationship of the soil 
samples. Standard methods (ASTM D698 and ASTM D1557) were used for estimating the laboratory compaction characteristics of soil using, respectively, standard effort $\left(6,000 \mathrm{kN}-\mathrm{m} / \mathrm{m}^{3}\right)$ and modified effort $\left(27,000 \mathrm{kN}-\mathrm{m} / \mathrm{m}^{3}\right)$ for the determination of the moisture-density relationship. The moisture content of each compacted soil specimen was calculated by finding the average of the two water contents.

The Atterberg limit test was carried out using Casagrande's apparatus and following the procedure described in ASTM D4318. The LL, the plastic limit (PL) and the plasticity index (PI) of the soil were determined.

\section{Data Processing and Interpretation}

\section{Characteristics of the VES Layers (Schlumberger Array)}

The summary and interpretation of the results, iterated using the IP2 computer software, are displayed in Table 1 . The results of the resistivity curves and the geo-electric sections, i.e. thickness of layers, resistivity, depth, inferred lithology and curve type values, are shown in Table 1.

The shape of a VES curve depends on the number of layers in the bedrock, the thickness of each layer and the ratio of the resistivity of the layers [34]; it also reflects the different lithological attributes in the study area. The results of the quantitative interpretation suggest that the sites are characterized by four types of resistivity curves, which are 4-AKH, 3-KH, 2-HA and $1-\mathrm{KQH}$. For example, curve $\mathrm{AKH}$ of the layer resistivity sections $(\rho 1<\rho 2<\rho 3>\rho 4>\rho 5)$ for VES-1, 2, 3 and 9 - after quantitative treatment and analysis - were delineated to five distinct geo-electric layers in the study area (top soil, laterite, which extends to the third geo-electric layer at some sites, and a fourth layer, which is sandy clay, with basement rock being the fifth layer).

Typical sounding curves and geo-electric section layers from the site include the $\mathrm{HA}\left(\rho_{1}>\rho_{2}>\rho_{3}<\rho_{4}\right)$, $\mathrm{KH}\left(\rho_{1}<\rho_{2}>\rho_{3}<\rho_{4}\right)$, AKH $\left(\rho_{1}<\rho_{2}<\rho_{3}>\rho_{4}<\rho_{5}\right)$ and $\mathrm{KQH}\left(\rho_{1}<\rho_{2}>\rho_{3}>\rho_{4}<\rho_{5}\right)$ curve types, with four to five geo-electric layer combinations. The $\mathrm{AKH}$ curve type predominates, constituting $40 \%$ of the total number of curves, while the $\mathrm{KH}, \mathrm{HA}$ and $\mathrm{KQH}$ types constitute $30 \%, 20 \%$ and $10 \%$ of this total, respectively. Concisely, a maximum of five geo-electric sub-surface layers were identified in the area, comprising the topsoil with resistivity values ranging from 47.8 to $381 \Omega-\mathrm{m}$ and thickness varying from 0.701 to $1.08 \mathrm{~m}$; the lateritic layer with resistivity values between 116 to $1,095 \Omega-\mathrm{m}$ and thickness varying from 0.596 to $2.08 \mathrm{~m}$; lateritic hard pan layer with resistivity values ranging from 22.5 to $480 \Omega$-m and thickness varying from 1.94 to $27 \mathrm{~m}$; and the fresh basement with resistivity range of 455 to $921 \Omega$-m which is assumed to be infinitely thick. The second layer in VES 4 and VES 5 is filled with sandy clay (Table 1); the two locations would not support engineering structures, except when the foundation is reinforced.

\section{Results of Geotechnical Tests}

\section{Compaction Limit Test}

The maximum dry density (MDD) for the soil samples ranged from 1,697 to $2,158 \mathrm{~kg} \cdot \mathrm{m}^{-3}$ while the optimum moisture content (OMC) ranged from $8.74 \%$ to $17.74 \%$ (Table 2). The values of the MDD for all samples were within the specifications of the Federal Ministry of Works and Housing, Nigeria [35], which recommends that the MDD should be $>1,680 \mathrm{~kg} \cdot \mathrm{m}^{-}$ ${ }^{3}$ and the $\mathrm{OMC}<18 \%$. The strength of the soil and the density of the soil mass are interrelated generally: the strength of a soil increases as its dry density increases. The potential for the soil to take on water at later times is decreased by higher densities, which is due to the decreased presence of air space in the soil mass. The inplace moisture content of a soil is often used, along with the soil classification, to determine the suitability of the material. Generally, as the moisture content of a soil increases, its strength decreases and its potential for deformation and instability increases.

\section{Sieve Analysis Test}

The percentage passing, percentage retained and the quantity of the soil passing were calculated using Equations 2, 3 and 4.

The percentages of soil samples L2, L4, L5, L6, L7, L8 and L10 by weight that passed through No. 200 sieve were within the specification lim- 
Table 1: Summary of the results of the VES for the study area

\begin{tabular}{|c|c|c|c|c|c|c|c|}
\hline VES & Location & Layer & $\begin{array}{c}\text { Apparent } \\
\text { resistivity } \\
(\rho)\end{array}$ & $\begin{array}{l}\text { Thickness } \\
\text { (m) }\end{array}$ & $\begin{array}{c}\text { Depth } \\
\text { (m) }\end{array}$ & $\begin{array}{l}\text { Inferred } \\
\text { lithology }\end{array}$ & Curve type \\
\hline 1 & $\begin{array}{c}\text { Lat } \\
7^{\circ} 13^{\prime} 38.49^{\prime \prime} \\
\text { Long } \\
3^{\circ} 25^{\prime} 50.87^{\prime \prime}\end{array}$ & $\begin{array}{l}1 \\
2 \\
3 \\
4 \\
5\end{array}$ & $\begin{array}{c}180.0 \\
417.0 \\
464.0 \\
59.0 \\
712.0\end{array}$ & $\begin{array}{c}0.70 \\
2.08 \\
1.94 \\
23.80\end{array}$ & $\begin{array}{c}0.70 \\
2.78 \\
4.72 \\
28.50\end{array}$ & $\begin{array}{c}\text { Topsoil } \\
\text { Lateritic } \\
\text { Lateritic } \\
\text { hard pan } \\
\text { Sandy clay } \\
\text { Basement } \\
\text { rock }\end{array}$ & $\mathrm{AKH}$ \\
\hline 2 & $\begin{array}{c}\text { Lat } \\
7^{\circ} 13^{\prime} 36.32^{\prime \prime} \\
\text { Long } \\
3^{\circ} 25^{\prime} 40.36^{\prime \prime}\end{array}$ & $\begin{array}{l}1 \\
2 \\
3 \\
4 \\
5\end{array}$ & $\begin{array}{c}180.0 \\
414.0 \\
472.0 \\
61.5 \\
841.0\end{array}$ & $\begin{array}{c}0.79 \\
1.95 \\
1.98 \\
23.80\end{array}$ & $\begin{array}{l}0.79 \\
2.74 \\
4.72 \\
28.5\end{array}$ & $\begin{array}{c}\text { Topsoil } \\
\text { Lateritic } \\
\text { Lateritic } \\
\text { hard pan } \\
\text { Sandy clay } \\
\text { Basement } \\
\text { rock }\end{array}$ & $\mathrm{AKH}$ \\
\hline 3 & $\begin{array}{c}\text { Lat } \\
7^{\circ} 13^{\prime} 33.48^{\prime \prime} \\
\text { Long } \\
3^{\circ} 25^{\prime} 40.52^{\prime \prime}\end{array}$ & $\begin{array}{l}1 \\
2 \\
3 \\
4 \\
5\end{array}$ & $\begin{array}{c}189.0 \\
417.0 \\
480.0 \\
63.5 \\
731.0\end{array}$ & $\begin{array}{c}0.70 \\
1.84 \\
2.06 \\
25.60\end{array}$ & $\begin{array}{c}0.70 \\
2.54 \\
4.60 \\
30.20\end{array}$ & $\begin{array}{c}\text { Topsoil } \\
\text { Lateritic } \\
\text { Lateritic } \\
\text { hard pan } \\
\text { Sandy clay } \\
\text { Basement } \\
\text { rock }\end{array}$ & $\mathrm{AKH}$ \\
\hline 4 & $\begin{array}{c}\text { Lat } \\
7^{\circ} 13^{\prime} 32.31^{\prime \prime} \\
\text { Long } \\
3^{\circ} 25^{\prime} 46.56^{\prime \prime}\end{array}$ & $\begin{array}{l}1 \\
2 \\
3 \\
4\end{array}$ & $\begin{array}{l}285.0 \\
116.0 \\
101.0 \\
610.0\end{array}$ & $\begin{array}{c}0.78 \\
0.64 \\
14.60\end{array}$ & $\begin{array}{c}0.78 \\
1.41 \\
16.00\end{array}$ & $\begin{array}{c}\text { Top soil } \\
\text { Sandy clay } \\
\text { Saturated } \\
\text { sandy clay } \\
\text { Basement } \\
\text { rock }\end{array}$ & HA \\
\hline 5 & $\begin{array}{c}\text { Lat } \\
7^{\circ} 13^{\prime} 40.36^{\prime \prime} \\
\text { Long } \\
3^{\circ} 25^{\prime} 43.47^{\prime \prime}\end{array}$ & $\begin{array}{l}1 \\
2 \\
3 \\
4\end{array}$ & $\begin{array}{c}381.0 \\
190.0 \\
25.4 \\
445.0\end{array}$ & $\begin{array}{c}1.01 \\
0.79 \\
10.00\end{array}$ & $\begin{array}{c}1.01 \\
1.80 \\
11.80\end{array}$ & $\begin{array}{c}\text { Top soil } \\
\text { Sandy clay } \\
\text { Saturated } \\
\text { sandy clay } \\
\text { Basement } \\
\text { rock }\end{array}$ & HA \\
\hline 6 & $\begin{array}{c}\text { Lat } \\
7^{\circ} 13^{\prime} 42.23^{\prime \prime} \\
\text { Long } \\
3^{\circ} 25^{\prime} 41.48^{\prime \prime}\end{array}$ & $\begin{array}{l}1 \\
2 \\
3 \\
4\end{array}$ & $\begin{array}{l}139.0 \\
178 / 0 \\
22.5 .0 \\
496.0\end{array}$ & $\begin{array}{l}1.01 \\
0.59 \\
7.38\end{array}$ & $\begin{array}{l}1.01 \\
1.60 \\
8.98\end{array}$ & $\begin{array}{c}\text { Top soil } \\
\text { Lateritic } \\
\text { Sandy clay } \\
\text { Basement } \\
\text { rock }\end{array}$ & $\mathrm{KH}$ \\
\hline 7 & $\begin{array}{c}\text { Lat } \\
7^{\circ} 13^{\prime} 38.95^{\prime \prime} \\
\text { Long } \\
3^{\circ} 25^{\prime} 47.59^{\prime \prime}\end{array}$ & $\begin{array}{l}1 \\
2 \\
3 \\
4\end{array}$ & $\begin{array}{c}81.5 \\
120.0 \\
47.1 \\
494.0\end{array}$ & $\begin{array}{c}0.74 \\
2.06 \\
27.10\end{array}$ & $\begin{array}{c}0.74 \\
2.80 \\
29.90\end{array}$ & $\begin{array}{c}\text { Top soil } \\
\text { Lateritic } \\
\text { Sandy clay } \\
\text { Basement } \\
\text { rock } \\
\end{array}$ & $\mathrm{KH}$ \\
\hline 8 & $\begin{array}{c}\text { Lat } \\
7^{\circ} 13^{\prime} 38.91^{\prime \prime} \\
\text { Long } \\
3^{\circ} 25^{\prime} 50.87^{\prime \prime}\end{array}$ & $\begin{array}{l}1 \\
2 \\
3 \\
4 \\
5\end{array}$ & $\begin{array}{c}129.0 \\
186.0 \\
67.8 \\
24.0 \\
656.0\end{array}$ & $\begin{array}{c}0.74 \\
1.56 \\
9.51 \\
19.40\end{array}$ & $\begin{array}{c}0.74 \\
2.30 \\
11.80 \\
31.20\end{array}$ & $\begin{array}{c}\text { Top soil } \\
\text { Lateritic } \\
\text { Sandy clay } \\
\text { Saturated } \\
\text { sandy clay } \\
\text { Basement }\end{array}$ & $\mathrm{KQH}$ \\
\hline 9 & $\begin{array}{c}\text { Lat } \\
7^{\circ} 13^{\prime} 37.46^{\prime \prime} \\
\text { Long } \\
3^{\circ} 25^{\prime} 53.07^{\prime \prime}\end{array}$ & $\begin{array}{l}1 \\
2 \\
3 \\
4 \\
5\end{array}$ & $\begin{array}{c}47.8 \\
120.0 \\
157.0 \\
48.7 \\
494.0\end{array}$ & $\begin{array}{l}1.08 \\
1.70 \\
3.86 \\
29.1\end{array}$ & $\begin{array}{c}1.08 \\
2.78 \\
6.64 \\
35.70\end{array}$ & $\begin{array}{c}\text { Top soil } \\
\text { Lateritic } \\
\text { Lateritic } \\
\text { hard pan } \\
\text { Sandy clay } \\
\text { Basement } \\
\text { rock }\end{array}$ & $\mathrm{AKH}$ \\
\hline 10 & $\begin{array}{c}\text { Lat } \\
7^{\circ} 13^{\prime} 36.77^{\prime \prime} \\
\text { Long } \\
3^{\circ} 26^{\prime} 1.76^{\prime \prime}\end{array}$ & $\begin{array}{l}1 \\
2 \\
3 \\
4\end{array}$ & $\begin{array}{c}600.0 \\
1,095.0 \\
53.0 \\
921.0\end{array}$ & $\begin{array}{c}0.79 \\
0.81 \\
18.10\end{array}$ & $\begin{array}{c}0.79 \\
1.60 \\
19.70\end{array}$ & $\begin{array}{c}\text { Top soil } \\
\text { Lateritic } \\
\text { Sandy clay } \\
\text { Basement } \\
\text { rock }\end{array}$ & $\mathrm{KH}$ \\
\hline
\end{tabular}


Table 2: Results of the Compaction Limits Determined for the Soil Samples

Sample Number

\begin{tabular}{crl}
\hline L 2 & 13.16 & 1,812 \\
\hline L 4 & 8.74 & 2,158 \\
\hline L 5 & 12.83 & 1,697 \\
\hline L 6 & 11.00 & 2,012 \\
\hline L 7 & 11.70 & 2,076 \\
\hline L 8 & 12.40 & 2,115 \\
\hline L 10 & 17.74 & 1,764 \\
\hline
\end{tabular}

Table 3: Summary of Results of Sieve Analysis

\begin{tabular}{cccccccccc} 
& Sieve Number & $\mathbf{4}$ & $\mathbf{8}$ & $\mathbf{1 6}$ & $\mathbf{3 0}$ & $\mathbf{5 0}$ & $\mathbf{1 0 0}$ & $\mathbf{2 0 0}$ & Pan \\
\hline & Diameter $(\mu \mathrm{m})$ & 475 & 236 & 118 & 600 & 300 & 150 & 75 & \\
\hline L2 & \% Retained & 13.22 & 15.28 & 18.54 & 12.61 & 18.83 & 16.86 & 3.25 & 1.4 \\
\hline & \% Passing & 86.78 & 71.5 & 52.96 & 40.35 & 21.51 & 4.65 & 1.4 & 0 \\
\hline L4 & \% Retained & 4.50 & 4.15 & 11.24 & 15.72 & 29.42 & 28.86 & 3.39 & 2.48 \\
\hline & \% Passing & 95.50 & 91.35 & 80.11 & 64.39 & 34.79 & 6.11 & 2.72 & 0.24 \\
\hline L5 & \% Retained & 11.49 & 13.12 & 24.19 & 11.99 & 17.79 & 15.46 & 2.47 & 3.28 \\
\hline & \% Passing & 88.51 & 75.39 & 51.2 & 39.21 & 21.42 & 5.96 & 3.49 & 0.21 \\
\hline L6 & \% Retained & 14.80 & 14.42 & 25.78 & 12.91 & 16.05 & 11.25 & 3.46 & 1.33 \\
\hline & \% Passing & 85.20 & 70.78 & 45 & 32.09 & 16.04 & 4.79 & 1.33 & 0.00 \\
\hline L7 & \% Retained & 10.03 & 11.72 & 20.03 & 12.11 & 19.76 & 18.94 & 4.02 & 2.35 \\
\hline & \% Passing & 89.97 & 78.25 & 58.22 & 46.11 & 26.35 & 7.41 & 2.39 & 0.04 \\
\hline L8 & \% Retained & 15.43 & 13.49 & 20.34 & 14.49 & 27.8 & 0.33 & 6.88 & 1.23 \\
\hline & \% Passing & 84.57 & 71.08 & 50.74 & 50.74 & 36.25 & 8.45 & 8.12 & 1.24 \\
\hline L10 & \% Retained & 9.06 & 11.66 & 24.79 & 11.12 & 18.09 & 20.9 & 2.61 & 1.77 \\
\hline & \% Passing & 90.94 & 79.28 & 54.49 & 43.37 & 25.28 & 4.38 & 1.77 & 0.00 \\
\hline
\end{tabular}

it, and they were $1.40 \%, 2.72 \%, 3.49 \%, 1.33 \%$, $2.39 \%, 8.12 \%$ and $1.77 \%$ (Table 3). The values were less than the stipulated maximum limit of $35 \%$ based on the specification requirement [35] in Clause 6201.

\section{Specific Gravity Test}

Table 4 shows the results of determination of the specific gravity of the soil samples.

Soil samples L2, L4, L5, L6, L7, L8 and L10 had specific gravities of $2.69,2.41,2.64,2.80,2.54$,
2.67 and 2.47 , respectively. The specific gravity of the samples was within the limit of specification [35] in Clause 6201, which ranges from 2.5 to 2.75 , except samples L4 and L6, which had values lower than and greater than the limit, respectively. The specific gravity of soil grains depicts vital information on the features of a soil, whether it can withstand engineering structures or not [36]. The closer the specific gravity of the soil to the upper limit of the standard of the soil, the better it is for construction purposes. 
Table 4: Results of the Average Specific Gravity Determination of Soil Samples

\begin{tabular}{ccccccccc} 
Sample Designation & L $\mathbf{~}$ & L 4 & L 5 & L 6 & L 7 & L 8 & L 10 \\
\hline First & 2.71 & 2.43 & 2.57 & 2.80 & 2.50 & 2.67 & 2.50 \\
\hline Second & 2.67 & 2.38 & 2.71 & 2.80 & 2.57 & 2.67 & 2.43 \\
\hline Average SP & 2.69 & 2.41 & 2.64 & 2.80 & 2.54 & 2.67 & 2.47 \\
\hline
\end{tabular}

Table 5: Liquid limit, average plastic limit and plasticity index percentage for the soil samples

\begin{tabular}{cccc} 
Station & Liquid Limit at N & Average Plastic Limit & Plasticity Index \% \\
\hline L2 & 23.54 & 14.75 & 8.79 \\
\hline L4 & 41.25 & 31.84 & 9.74 \\
\hline L5 & 17.20 & 0.00 & 17.20 \\
\hline L6 & 21.83 & 16.10 & 5.73 \\
\hline L7 & 30.49 & 12.91 & 8.79 \\
\hline L8 & 34.74 & 22.95 & 11.79 \\
\hline L10 & 32.74 & 21.04 & 11.70 \\
\hline
\end{tabular}

Table 6: Results of the Determined California bearing ratio test for the soil samples.

\begin{tabular}{ccc} 
Sample Number & Unsoaked CBR (\%) & Soaked CBR (\%) \\
\hline L 2 & 97.82 & 22.40 \\
\hline L 4 & 56.78 & 4.20 \\
\hline L 5 & 108.00 & 13.70 \\
\hline L 6 & 94.48 & 15.78 \\
\hline L 7 & 96.34 & 22.90 \\
\hline L 8 & 110.00 & 29.50 \\
\hline L 10 & 120.00 & 19.30
\end{tabular}

\section{Atterberg Limit Results}

The values of LL, PL and PI are presented in Table 5.

All soil samples except L4 and L5 satisfied the specification requirement [35] in clauses 6201 and 6252 since both the LL and PI (Table 5) of all the samples did not exceed the stipulated values of $35 \%$ and $12 \%$, respectively. The PI of soil sample L5 was above the standard limit; therefore, it is considered to be highly plastic (i.e. it is clayey), which may pose a threat to the structure (leading to structural failure) since the soil usually has the ability to retain appreciable amount of water (moisture), especially by absorption, thereby decreasing its permeability and hydraulic conductivity (K).

\section{CBR Test}

The overall CBR for soaked (CBR_s) and unsoaked (CBR_u) soil samples were within the specified limits except the sample at L4 (Table 6).

The specification requirement [35] is that the minimum strength of the material shall not be $<80 \%$ for CBR_u, while the minimum strength of the material shall not be $<10 \%$ after at least 48 hours of soaking (CBR_s). The CBR_s and CBR_u values for L4 were $4.20 \%$ and $56.78 \%$, respectively. These values indicate that the soil at VES 4 is a clayey lateritic soil, which does not support heavy structures. In addition, moisture influx would be highly detrimental to the structure constructed at this position. 

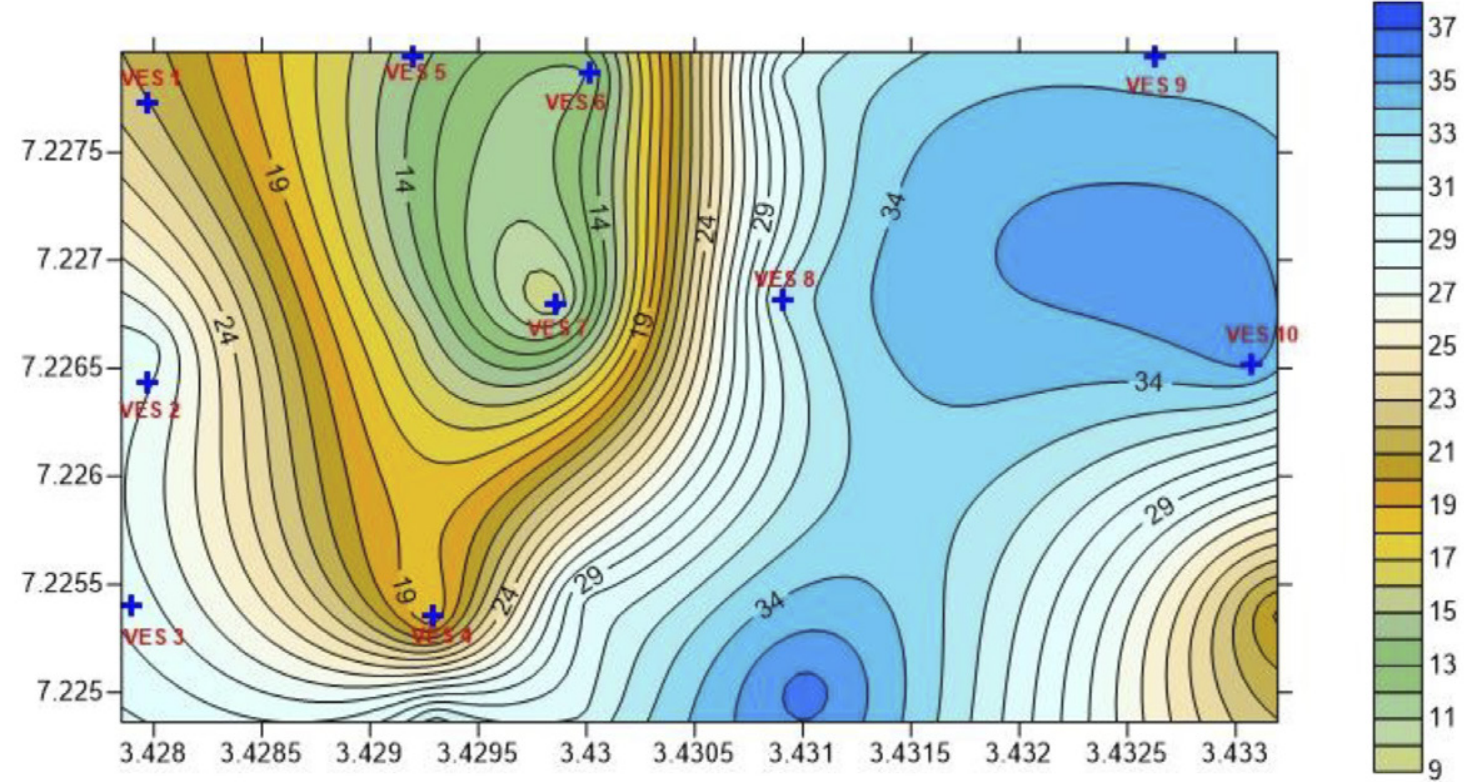

Figure 5: Overburden thickness map of the study area.
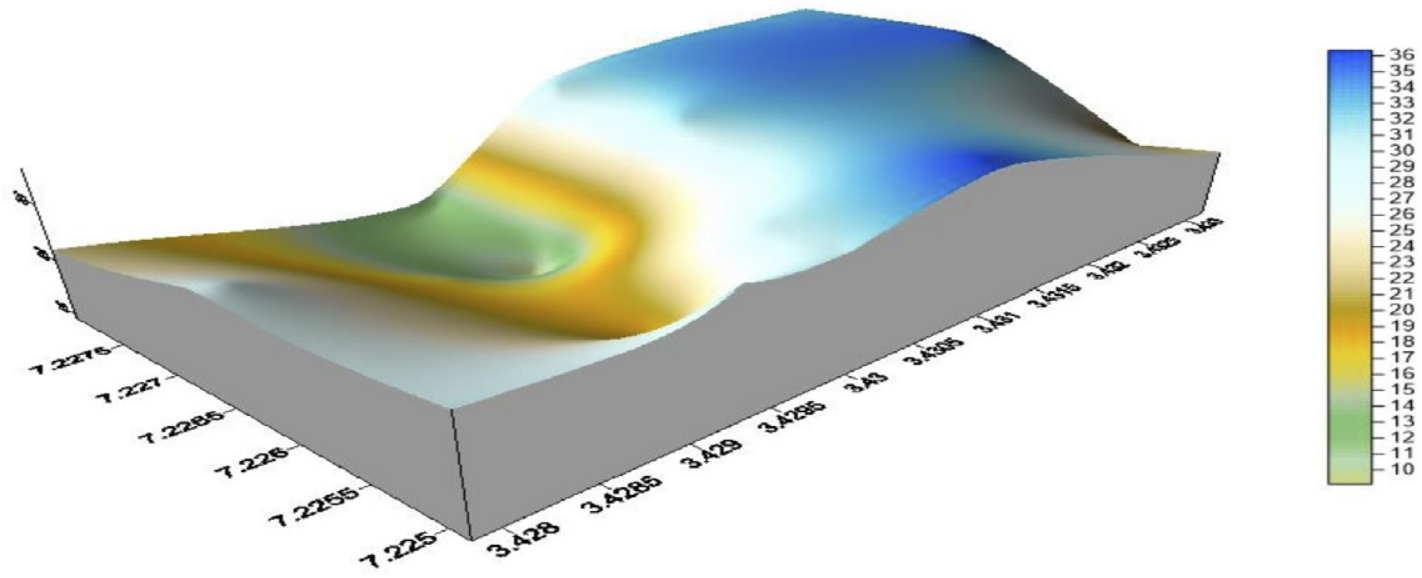

Figure 6: Basement relief map of the study area.

\section{Hydrogeological Implication}

It is possible to make qualitative hydro-geological deductions from the curve types [37]. The aquiferous zones are found within the layer with relatively low resistivity values (Figure 5). This zone is interpreted as the underlying groundwater level. Consequently, because of the low resistivity of the aquiferous units in Table 1 , the positions VES 5, VES 6 and VES 8 are favourable points for locating a well. Basically, the absolute value of electrical conductivity has been effectively used. The overburden thickness map of the area (Figure 6) indicates the zones of rela- tively thick overburden (i.e. $>16 \mathrm{~m}$ ) and zones of relatively thin overburden (i.e. $<16 \mathrm{~m}$ ). From studies in similar basement terrain [38], areas with thick overburden cover are identified as high-groundwater-potential zones. Likewise, the analysis of the bedrock relief map of the site (Figure 5) has hydro-geological significance in a basement setting [39]. Basement depression zone (i.e. area at lower elevation on the bedrock) is delineated at the eastern part of the study area. The thick overburden and depression zones constitute priority areas for groundwater development. 


\section{Geotechnical Implication}

The engineering competence of the sub-surface formation in the study area was evaluated qualitatively from layer resistivity characteristics: the higher the layer resistivity, the higher the competence [40]. The relatively low resistivity anomaly $(116 \mathrm{Wm})$ beneath VES 4 depicts a fracture or weak shear zone, which is a potential hazard to settlement of buildings and may cause collapse of overlying structures if remedial engineering action is not considered.

\section{Conclusion}

The geophysical and geotechnical methods of foundation investigations carried out at the proposed site for a hostel in the campus of Federal University of Agriculture, Abeokuta, have been effective in characterising the sub-surface materials that underlie the study area as well as the depth to bedrock. The results obtained from the VES experiments show a maximum of five geo-electric layers, which include topsoil, lateritic, lateritic hard pan, sandy clay and basement/fractured basement rock. The geo-electric section reveals that the second layer of VES 4 and VES 5 are filled with sandy clay, which is not suitable for structure foundation. The CBR test reveals that all the soil samples tested - except L4 (taken at VES 4) - are mechanically stable and have high load-bearing capacity, which is suitable for both shallow and deep foundations without the need for reinforcement. However, reinforcement is highly required in the design and construction of the foundation in VES 4. The Atterberg limit test and the geo-electric section reveal that the second layer of VES 4 is filled with sandy clay with high PI and low LL, which may pose a threat to the foundation (leading to structural failure), since the soil usually has the ability to retain appreciable amount of water (moisture) especially by absorption, thereby decreasing its permeability and hydraulic conductivity. The positions of VES 5, VES 6 and VES 8 are identified as high-groundwater-potential zones in the study area, which are suitable locations for hand-dug wells and boreholes for optimum groundwater abstraction. The results from the application of geophysical and geotechnical methods on site characterization reveal that the study area is suitable for both shallow and deep foundations, except at VES 4 and VES 5, where reinforcement is required to support shallow and deep foundations.

\section{References}

[1] Marshall, R., Martin, M. (1993): Defect Prevention Research Project. Canada Mortgage and Housing Corporation/Ontario New Home Warranty Program.

[2] Fagbenle, O.I., Oluwunmi, A.O. (2010): Building Failure and Collapse in Nigeria: the Influence of the Informal Sector, Journal of Sustainable Development, 3(4), pp. 268-276.

[3] Dimuna, K.O. (2010): Incessant Incidents of Building Collapse in Nigeria: A Challenge to Stakeholders. Global Journal of Researches in Engineering, 2 (4), pp. 75-84.

[4] Adebowale P.A, Gambo, M.D., Ankeli, I.A., Daniel, I.D. (2016): Building Collapse in Nigeria: Issues and Challenges. Conference of the International Journal of Arts \& Sciences, 9(1), pp. 99-108.

[5] Leonards, G.A. (1982): Investigation of failures. Journal of Geotechnical Engineering, ASCE, 108, pp. 187-246.

[6] Chendo, I.G., Obi, N.I. (2015): Building collapse in Nigeria: the causes, effects, consequences and remedies. International Journal of Civil Engineering, Construction and Estate Management, 3(4), pp.41-49.

[7] Robert, J.N., (2010): Geotechnical Site Characterization and Field Investigation Methods; Anticipate and Identify Subsurface Conditions to Manage Risks. Whitlock dalrymple poston \& associates, p.c.

[8] Oyedele, K.F., Oladele, S., Adedoyin, O. (2011): Application of Geophysical and Geotechnical Methods to Site Characterization for Construction Purposes at Ikoyi, Lagos, Nigeria. Journal of Earth Sciences and Geotechnical Engineering. 1(1), pp. 87-100.

[9] Wightman, W.E., Jalinoos, F., Sirles, P., Hanna, K. (2003): Application of Geophysical Methods to Highway Related Problems. Lakewood. Federal Highway Administration, Central Federal Lands Highway Division, Publication.

[10] Soupios, P.M., Georgakopoulos, P., Papadopoulos, N., Saltas, V., Andreadakis, A., Vallianatos, F., Sarris, A., Makris, J.P. (2007): Use of engineering geophysics to investigate a site for a building foundation. Journal of Geophysics and Engineering, 4, pp. 94-103. 
[11] Abu-Shariah, M.I.I. (2009): Determination of cave geometry by using a geo-electrical resistivity inverse model. Engineering Geology, 105, pp. 239-244.

[12] El Mahmoudi, A.S., Khalied, M.A., Massoud, A.M. (2010): 2-D electrical tomography for mapping of aquifer at the new campus of King Feisal University, Al Hassa, KSA. 4th International Conference on Water Resources and Arid Environments (ICWRAE4), pp. 267-280.

[13] Olorunfemi, M.O., Ojo, J.S., Ojelabi, E.A. (2002): Geophysical Site Investigation of the premises of Idu Flow Station. Nigerian Agip Company (NAOC) Limited. (For multipurpose Oil Services Company Limited, Port Harcourt). Technical Report.

[14] Adeoti, L., Kehinde, I., Adegbola, R.B., Sovi, S.T. (2009): Foundation Investigation using Electrical Resistivity Method: A Case Study of Iponri, Lagos State, Nigeria. Journal of Engineering Research, 14(1), pp. 50-57.

[15] Ayolabi, E.A., Folorunso, A.F., Oloruntola, M.O. (2010): Constraining Causes of Structural Failure using Electrical Resistivity Tomography (ERT): A Case Study of Lagos, Southern Western, Nigeria. Journal of Geophysics/Mineral Wealth, 156/210, pp. 7-18.

[16] Adeyemo, I.A., Omosuyi, O.G. (2012): Hydrogeologic, Electrical and Electromagnetic Measurements for Geotechnical Characterization of Foundation Beds at Afunbiowo, near Akure, Southwestern Nigeria. Indian Journal of Science and Technology, 5(2).

[17] Salami, B.M, Falebita, D.E, Fatoba, J.O, Ajala, M.O. (2012): Integrated Geophysical and Geotechnical Investigation of A Bridge Site - A Case Study of A Swamp/Creek Environment in Southeast Lagos, Nigeria. Ife Journal of Science, 14(1), pp. 75-82.

[18] Fatoba, J.O., Alo, J.O., Fakeye, A.A. (2010): Geoelectric Imaging for Foundation Failure Investigation at Olabisi Onabanjo University Minicampus, Ago-Iwoye, Southwestern Nigeria. Journal of Applied Sciences Research, 6(12), pp. 2192-2198.

[19] Bharti, A.K., Pal, S.K., Priyam, P., Pathak, V.K., Kumar, R., Ranjan, S.K. (2016): Detection of illegal mine voids using electrical resistivity tomography: The casestudy of Raniganj coalfield (India). Engineering Geology, 213, pp. 120-132.

[20] Ayolabi, E.A., Folorunso, A.F., Jegede, O.E. (2012): An Application of 2D Electrical Resistivity Tomography in Geotechnical Investigations of Foundation Defects: A Case Study. Journal of Geology and Mining Research, 3(12), pp. 142-151.

[21] Bayode, S., Omosuyi, G.O., Abdullahi, H.I. (2012): Post -foundation Engineering Geophysical investigation in Part of the Federal University of Technol- ogy, Akure, Southwestern Nigeria. Journal of Emerging Trends and Engineering Apply Science, 3(1), pp. 203-210.

[22] Faseki, O.E., Olatinpo, O.A, Taiwo, O.B. (2016): Ground Investigation of an Engineering Site at Point Road, Apapa, Lagos, Nigeria. Journal of Engineering and Energy Research, 6(1), pp. 1-20.

[23] Oyedele, K.F., Adeoti, L., Oladele, S. Kamil, A. (2014): Investigation of a Proposed Four Story Building Sites Using Geophysical and Laboratory Engineering Testing Methods in Lagos, Nigeria. International Journal of Scientific Research in Knowledge, 2(2), pp. 83-91.

[24] Grant, N.K. (1978): Structural Distinction between a Metasedimentary Cover and an underlying Basement in the 600 m. y. old Pan African domain of Northwestern Nigeria, West Africa. Geological Society of American Bulletin, 89, pp. 50-58.

[25] Rahaman, M.A. (1976): Review of the Basement Geology of South-Western Nigeria. In: Kogbe CA (ed.) Geology of Nigeria, 2nd ed. Elizabethan Publishers, Lagos, pp. 41-58.

[26] Adegoke, A., Ajayi, O.W. (1988): Groundwater Prospects in Basement Complex Rock of South Western Nigeria. Journal of African Earth Sciences, 7(1), pp. 227-235.

[27] Odusanya, B.O, Amadi, U.N.P. (1990): An Empirical Resistivity Model for Predicting Shallow Groundwater in the Basement Complex Water Resources. Journal of Nigerian Association of Hydrologists, 2, pp. 77-87.

[28] Ako, B.D. (1979): Geophysical prospecting for groundwater in parts of South-western Nigeria. Unpublished PhD Thesis. Department of Geology, University of Ife, Ile-Ife, Nigeria. 371 p.

[29] Koefoed, O. (1979): Geo sounding Principles Resistivity: Sounding measurements. Elsevier Scientific Publishing Company, Amsterdam, 275 p.

[30] Alile, O.M, Amadasun, C.V.O, Evbuohuwan, A.I. (2008): Application of Vertical Electrical Sounding Method to Decipher the Existing Subsurface Stratification and Groundwater Occurrence Status in a Location in Edo North of Nigeria. International, Journal of Physical Sciences, 3(10), pp. 245-249.

[31] Milson, J. (1939): Field Geophysics; a handbook of geophysical society of London. John Wiley and Sons, New York, Toronto, Singapore.

[32] Reinhard, K.F. (1974): Combined geo-electrical and Drill-hole investigation for detecting fresh-water aquifers in Northern western Missouri. Geophysics, 39, pp. 340-352. 
[33] Dorbrin, M.D., King, R.F. (1976): Introduction to Geophysical Prospecting. Me Graw-Hill book, New York, $630 \mathrm{p}$.

[34] Schwarz, S.D. (1988): Application of Geophysical Methods to Groundwater Exploration in the Tolt River Basin, Washington State. Geotechnical and Environmental Geophysics, 1, pp. 213-217. http://dx.doi.org/10.4133/1.2921817.

[35] Federal Ministry of Works and Housing (1997): General specifications for Roads and Bridges. Vol II, Federal Highway Department, FMWH, Lagos, Nigeria, 168 p.

[36] Gidigasu, M.D. (1976): Laterite Soil Engineering. Elsevier Scientific Publishing Company, Amsterdam, 554 p.

[37] Worshington, P.R. 1977: Geophysical Investigations of Groundwater Resources in the Kalahari Basin. Geophysics, 42(4), pp. 838-849.
[38] Omosuyi, G.O., Ojo, J.S., Enikanselu, P.A. (2003): Geophysical Investigation for Groundwater around Obanla -Obakekere in Akure Area within the Basement Complex of South-Western Nigeria. Journal of Mining and Geology, 39(2), pp. 109-116.

[39] Bala, A.C. Ike, E.C., (2001): The Aquifer of the Crystalline Basement Rocks in Gusau Area, Northwestern Nigeria. Journal of Mining and Geology, 37(2), pp. 177-184.

[40] Hunt, R.E. (2007): Geotechnical Investigation Methods: A Field Guide for Geotechnical Engineers. Taylor \& Francis Group, LLC. pp 48. 